Vol. 29, No. 2

December 2002

Vangermeersch Manuscript Award Winner, 2001

Marta Macías

UNIVERSIDAD CARLOS III MADRID

\title{
PRIVATIZATION AND MANAGEMENT ACCOUNTING SYSTEMS CHANGE: THE CASE OF THE 19TH CENTURY SPANISH TOBACCO MONOPOLY
}

\begin{abstract}
This paper examines changes to the accounting system of the Spanish tobacco monopoly in 1887, following the decision by the state to lease the publicly owned and state-run monopoly to a privatesector company. The switch to private-sector management generated a fundamental change in the demands made of the accounting system. As a result, double-entry bookkeeping and a new method of calculating costs were implemented. The paper discusses the motives behind the design of the new accounting system and its consequences using the framework provided by agency theory. It highlights the need to consider the role of the capital structure of the firm and the state as explanatory factors for both the parameters and uses of cost accounting information.
\end{abstract}

\section{INTRODUCTION}

Contributions addressing the emergence of cost accounting practices in organizations have provided important insights into the broader processes involved in the production of accounting information. Competitive pressures [e.g., Johnson and Kaplan, 1987; Edwards and Newell, 1991; Fleischman and Parker, 1991,

Acknowledgments: Special thanks are due to Richard Fleischman and Marcia Annisette for helpful comments and assistance in preparing the manuscript. Comments by the members of the Vangermeersch Manuscript Award Committee, the attendants of the II Workshop in Accounting and Management in Historical Perspectives (Seville, 1999) and the 2001 Research Conference of the Academy of Accounting Historians (Santa Fe), and referees for AHJ are greatly appreciated. Financial support from a DGCYT grant (SEC2001-0890) is gratefully acknowledged. 
1997], enforcement of disciplinary practices [e.g., Hoskin and Macve, 1986, 1988], and the quest for greater labor productivity [Hopper and Armstrong, 1991] have been highlighted as underpinning the development of cost management systems. Much of this research has focused on Anglo-American settings characterized by strong, competitive environments. In spite of several contributions on the role of government agency [e.g., Ezzamel et al., 1990; Tyson, 1993], evidence about the nature of and motives behind such practices in other contexts is still needed. This paper, by examining the privatization of the Spanish tobacco monopoly in 1887, will explore the impact of ownership structure on management accounting systems. This privatization did not entail changes either in the competitive environment or in the productive technology used by the industry, allowing us to isolate the influence of the shift from public to private ownership on such practices. Archival evidence was gathered from three primary sources. The Archive of the Tobacco Company (Archivo de Histórico de la Fábrica de Tabacos de Sevilla, AHFTS) and the Intermediate Archive of the Tobacco Company (Archivo Intermedio de la Fábrica de Tabacos de Sevilla) constitute comprehensive sources for understanding internal developments at the tobacco factory. In addition, the Bank of Spain houses the Archive of the Bank of Spain (Archivo Histórico del Banco de España, AHBE), which is essential for investigating the privatization of the tobacco monopoly.

In recent times, the Spanish tobacco monopoly has been extensively studied. Carmona et al. [1997] examined from a Foucauldian perspective the implementation by 1773 of a cost accounting system. They showed cost calculations to be part of a strong disciplinary regime that enhanced visibility and served to establish a system of calculability that rendered human accountability visible. Carmona et al. [1998] used an institutional theory framework to explain changes to financial and cost accounting practices throughout the period from 1760 to 1790 . They concluded that new accounting practices emerged as a means of enhancing the external legitimacy of the organization. Carmona and Macías [2001] studied the implementation of budgets and cost accounting procedures in the period from 1820 to 1887. They focused on the state's motivation in exerting institutional pressures aimed at the implementation of early cost management practices and studied different organizational responses to simultaneous pressures arising from a single institutional source. In the period analyzed in all these papers, the monopoly was publicly owned and state-run. Finally, Macías 
[2002] explored determinants of accounting disclosure by analyzing the evolution of corporate financial reporting throughout the first leasing contract (1887-1896). The current paper also analyzes the impact of the privatization process but is significantly different in its exploration of the factors driving the design of management accounting information at the factory level, the tobacco factory of Seville being the unit of analysis. It is argued that the shift from public to private management entailed a fundamental change in the philosophy of management, with profitability and efficiency being privileged. Thus, a new demand for accounting information emerged with an appropriately redesigned accounting system.

The remainder of the paper is divided into five sections. In the next section, the theoretical framework is discussed. The historical context, the characteristics of the tobacco industry and the privatization process is then discussed. The subsequent section deals with the impact of privatization on management accounting systems. This is followed by a discussion of findings and conclusions.

\section{THEORETICAL FRAMEWORK}

Agency theory has highlighted the influence of different divisions of property rights in the emergence of efficient organizational forms [Jensen and Meckling, 1976]. The definition of property rights affects both the incentive schemes and the design of control mechanisms that regulate the relationship between principal and agent. In state-owned firms, the diffuse nature of ownership provides owners with low incentives to control management. Managers of state-owned firms may behave in ways which are not consistent with the interests of owners for three main reasons: (i) the existence of multiple objectives [Rees, 1984; Utton, 1986]; (ii) the absence of tight, external controls given no threat of take-over [Wright and Thompson, 1994] or bankruptcy exist [Kornai, 1986; Vickers and Yarrow, 1988; Stiglitz, 1989]; and, (iii) the existence of soft, internal control. Monitoring systems are expected to be bureaucratic, focusing on legal aspects [Bös, 1991]. Private ownership, on the contrary, is assumed to enhance management accountability and improve performance [Donahue, 1989; Jensen, 1989; Zeckhauser and Horn, 1989; Goodman and Loveman, 1991]. The assumption that ownership per se creates an environment that is conductive to high or low performance has been contested [Aharoni, 2000, p. 50]. Economic literature has tradition- 
ally focused on Anglo-Saxon and other developed economies in which privatization has been undertaken through the selling-off of public enterprises in a context of simultaneous deregulation and the prevalence of external control mechanisms. However, this scenario is not always the case. Recent literature on privatization [e.g., Dharwadkar, 2000; Ramamurti, 2000] has examined the situation in emerging economies where neither capital markets nor economic institutions are well-developed, emphasizing the importance of government's residual ownership and the type of capital the firm attracts to understand the results of privatization cases. Post-privatization operations of the firm and the strategy of the acquirer may be heavily influenced by the terms stipulated by government [Freudenberg and Bird, 1991; Uhlenbruck and DeCastro, 1998]. The outcome of privatization is not always the same type of private firm. Therefore, factors such as national characteristics, the role of the state, and the internal organization of the privatized firm may explain changes in management concerns and the behavior that follows privatization processes [Lenway and Murtha, 1994; DeCastro and Uhlenbruck, 1997; Uhlenbruck and DeCastro, 1998; Aharoni, 2000].

This paper addresses a privatization process with strong similarities to the situation that exists when control mechanisms develop in emerging economies. The paper attempts to explain changes to the management of the tobacco monopoly following the 1887 privatization and its implications for accounting systems. Accounting systems are part of those organizational mechanisms that monitor and evaluate the decision-making behavior of agents, representing an important issue for understanding the differences between public and private management [Fama and Jensen, 1983].

\section{THE EVOLUTION OF THE TOBACCO MONOPOLY: FROM HIERARCHICAL TO CONTRACTUAL ARTICULATION}

The tobacco industry was monopolized in 1637, becoming one of the main fiscal monopolies in Spain. Fiscal monopolies are legal reservations for private firms to engage in certain economic activities, acquiring from the state exclusive rights for the provision of a product or service and giving rise thereby to a double-layer, agency relationship. The state acts as an agent for citizens as the ultimate owners but simultaneously becomes a principal by granting the monopoly. When the state is the principal in an agency relationship, two crucial issues emerge [Lane, 
1997]: (i) the public or private nature of the agent with which the government is willing to interact, and (ii) the way in which this interaction is articulated. This can be broadly classified in hierarchical or contractual relationships. The election of a private or public agent concerns institutional arrangements; that is, how to regulate, contract, and control so as to impact directly the incentives and sanctions that encourage managers to improve performance [Bös, 1991; Odgen and Watson, 1996].

The monopolization of the Spanish tobacco industry was at first seen as a way of avoiding technical problems in tax collection and of minimizing corruption through the implementation of more direct control [Maureta, 1975]. While the tobacco monopoly was enacted in 1637, some private activities were maintained. In 1731, however, the state took full control of the industry, concentrating manufacturing in the factory of Seville and creating a special department (Steering Agency at the Treasury Ministry, SATM) to manage it. Direct management, it was thought, would generate an increase in the state's revenues through an improvement of control and efficiency [Rodríguez Gordillo, 1990].

The Tobacco Industry in the 19th Century: Since the early years of the 19th century, the organization of the tobacco industry underwent dramatic changes linked to political and ideological developments. In 1830, the last absolutist king, Fernando VII, died and the country entered into a long and far reaching period of change. The transition from the ancien régime to a modern state implied major institutional reforms. With regard to the organization of economic activities, liberals began a process of deregulation and dismantling of state-owned enterprises. This process never crystallized in the case of the tobacco monopoly despite the ideological opposition of liberals to monopolies. The financial distress of the state and the importance of the tobacco industry to the state's finances (in the 19th century it represented, on average, $12.5 \%$ of ordinary income) aborted every attempt to deregulate the monopoly. The liberal courts of Cadiz made the first move towards liberalization in September 1813, but as soon as the political situation reversed in 1814, the monopoly was reinstated. In 1821 liberals gained political power and the tobacco industry was likewise deregulated. However, a decrease in the state's income and a political change provoked a reversal in the government's mind and a return to the monopoly. In 1844 , the tobacco industry was leased to a private company, and, again, a political change ended in the restoration of direct 
management by the Treasury. In 1852, Parliament began to discuss the deregulation, and a new proposal of liberalization was included in the Constitutional Law of 1855. Once more, political change impeded implementation. In April 1866, there was a partial deregulation of the tobacco industry, affecting only the Spanish colonies of Cuba and Puerto Rico. This measure lasted just a few months. The Revolution of 1868 brought further changes. In June 1869, the tobacco and salt industries were deregulated, but, in 1871, the situation was again reversed as the monopoly was re-imposed. Finally, in 1887, management of the industry was leased to a private company.

By the time of privatization, the tobacco industry was large and complex. The industry was comprised of different operating units. Acquisition was organized by the SATM and the Dirección General de Contabilidad through agents at a number of places (Spain, the U.S., the American colonies, and the Philippine Islands). Manufacturing operations were developed in nine factories, managed by the SASM, though the Dirección General del Tesoro Público was in charge of cash operations. Sales and distribution were also organized by the Dirección General del Tesoro Público through a system of provincial and local warehouses that supplied more than 18,000 tobacconists. Finally, one of the critical aspects of the industry, the fight against smuggling, was within the purview of the Army. The industry endured a tension between subordination to the administrative hierarchy, while at the same time exhibiting a certain level of economic and accounting flexibility [Tejerizo López, 1975]. Whereas a degree of independence in its functioning existed, a subordination to hierarchical rules and bureaucratic procedures anchored efficient management, especially in the context of a political instability that led to a high turnover of the ministry's head officers. This in turn impaired consistency in reform efforts throughout the century.

The tobacco industry employed approximately 32,000 manufacturing workers, most of them female. Within the factories, work was organized by product lines [García de Torres, 1884]. Each product line (cigars, plug tobacco, cigarettes, and, subsequently, snuff) constituted a "factory" under the charge of an operating manager, assisted by several middle managers. Factories were composed of a number of workshops directed by a maestra. Maestras, middle managers, and operating managers were state employees. They received a monthly salary and were charged with controlling the production process and recording the flow of tobacco leaves and products. The rest of the work 
force received piece rates that corresponded in amount to the complexity of the product manufactured. Tobacco leaves were distributed daily to the workshops with the physical flow of tobacco recorded by the maestras. They were also responsible for assessing the conformity of final products to quality requirements. Careful tracking of the production of each worker was kept and served as the basis for wage payment. Operating managers also kept records of the tobacco distributed and the final products received from the different workshops.

Piece rates and the composition of tobacco products were fixed by a number of legal regulations. Both were established when a new product was launched. In these cases, experiments were run to determine the blend of tobacco and the time spent in manufacturing so that an adequate salary could be determined based upon the difficulty of the task. Although extensive legislation covered every aspect of work in the factories, a lack of uniformity became a major concern for the ministry as the industry expanded. Regulations covered the blend of different tobacco leaves for each product, the proportion between input and output, and other technical specifications such as length, thickness, or weight of final products. As time passed, these rules hardened into production standards, impairing improvements in efficiency as they were seldom revised [Comín and Martín Aceña, 1999]. Additionally, in spite of the extensive regulation, uniformity was difficult to achieve because the quality, as well as the physical aspect of the final product, was highly dependent upon the dexterity of individual workers, the quality of the tobacco leaves received, and the speed with which products were distributed to consumers.

While the Treasury attempted to increase centralization in decision making throughout the century, the growth of the industry and the political circumstances affecting public administration served to divorce decision making from action [see Carmona and Macías, 2001]. For instance, Delgado [1896] considered that the organization of the factories by 1887 was "as diverse as the number of factories."

The Privatization of the Tobacco Monopoly: The motivations for privatizing the tobacco monopoly derived from the difficulties the government faced in balancing the public budget. By 18871888 , according to the state's general budget, the funding needs rose to $65,812,000$ pesetas [Instituto de Estudios Fiscales, 1976]. The tobacco industry was a profitable activity in spite of the previously mentioned efficiency problems. It represented one of 
the main sources of income for the state, but the government considered that the contribution of tobacco to the public finances could increase if certain reforms were implemented. Throughout the century, the industry faced a quasi-permanent excess of demand which the state had tried to address through an expansion of the number of factories [Alonso Alvarez, 1996]. At the time of privatization, new technologies had become available, so the required expansion could have been achieved either through the mechanization of the production process or by adding more factories to the existing ones. Both these alternatives implied the allocation of additional resources to the industry. Additionally, a speedy reform under public management was thought to be difficult to achieve, so the chosen alternative was to lease the industry's management to a private firm, something that would perpetuate state control and simultaneously facilitate the introduction of the required reforms [Torres Villanueva, 1998].

Moreover, according to the Treasury Minister, the maintenance of public management addressed another problem. The turnover of head officers in the ministry created serious difficulties in the design and implementation of a reform agenda. Private management, by contrast, with the incentive of significant, though deferred gains, would implement the required reforms to enhance performance.

The law authorizing the lease of the tobacco monopoly was enacted on April 22, 1887. The law required that the lessee be a Spanish company, independent of foreign groups, and that the duration of the lease be fixed at 12 years. The contractor was subject to a yearly rental, composed of a fixed amount (canon) plus a variable amount that depended on yearly profits. The term of the contract was divided into four sub-periods for calculation purposes. The canon consisted of a moving average, the amount to be paid calculated as follows. For the first three years, the canon was 90 million pesetas. For the second subperiod, the fixed amount would be the average of only the second and third years. A like computation was performed for the third and fourth sub-periods, the canon being the average of the prior sub-period. The variable part of the payment depended on the difference between net income and the canon. If net income was lower than the fixed amount established for that period, the contractor would bear the loss. In the opposite case, the surplus was shared equally between the state and the lessee.

The contractor was to maintain the existing factories, build three new warehouses in the first three years of the contract, 
and construct three new factories with all the modern advances [Art. 8, Law 22nd, April 1887] during the first half of the contract. These investments were to be repurchased by the state at the term of the contract, thus requiring the previous approval of the Treasury Minister. The lessee would take over all the contracts signed by the Treasury. Once expired, the lessee could begin to contract with new suppliers. However, the government, in order to promote agricultural development, imposed the requirement that a certain volume of tobacco leaves had to be imported from the colonies and the Canary Islands.

The lessee had to preserve the number, types, and prices of existing products. While modifications to existing products required the approval of the Treasury, innovations only required notification to the Steering Agency. The contract established a distinction between employees (managers and clerks, formerly state employed) and workers. The lessee was committed to maintain at least $75 \%$ of the workers employed in the factories in 1886-1887. The hiring of new employees was not regulated. The lessee could hire its own employees, who would be subject to private rules rather than laws formerly imposed by the state.

Finally, a public monitoring system was devised. This was grounded in three fundamental bases: (i) intervention and direct control, (ii) a fee to assure the proper care of productive assets, and (iii) the imposition of a system of penalties that could imply the rescission of the contract. Direct control and intervention were the responsibility of a governmental delegate who would work at the head offices of the lessee, at the expense of the contractor. The delegate's duties included the physical inspection of different business locations, raw materials, and production, as well as the audit of accounting records, whether at the corporate or factory level. The main concern was to monitor the regularity of accounting operations. The governmental delegate could veto any decision that could harm the state's interests. The contract included legal sanctions for any potential breach of the contract. While the sanctions were mainly financial penalties, they could lead to the rescission of the contract.

The strict conditions imposed by the law and the resources required to run the tobacco industry ${ }^{1}$ may have inhibited the

${ }^{1}$ The contract included the possibility for the state to obtain a loan from the lessee [Art. 19]. The amount of this loan was fixed at 8 million per remaining year of the contract which meant that, at the time of the concession, the State could claim 96 million pesetas. Additionally, the contract required the lessee to deposit a fee [20 million]. Loan, fee, and minimum rental [90 million] repre- 
bidding process. Additionally, the importance of the tobacco monopoly for the state's finances forced the government to be very cautious over its choice of agent. Therefore, while the proposal of the leasing law was being discussed by Parliament, the government began a bargaining process with a particular candidate, the Bank of Spain, which at that time was a private company, but one that was highly dependent upon its relationships with the state. ${ }^{2}$ The government knew that with the Bank being in charge of the tobacco industry, there would be no threat of bankruptcy or fraud since all the Bank's other relationships served as collateral. Additionally, the Bank commanded the required financial resources needed to develop the industry. The government exerted a strong pressure on the Bank to assure that the tobacco industry would be assigned to it despite the existence of other bidders. In order to avoid competition in the bidding process, the Bank's board contacted these other potential investors and brought them together in a joint proposal. Bank and investors came to a private agreement before the law was enacted on April 22, 1887. Immediately after winning the bid, the Bank and these investors founded the Compañia Arrendataria de Tabacos (CAT) to run the business.

The capital of the firm was initially 60 million pesetas of which the Bank of Spain held one half, either directly or indirectly, thus assuring its control of the CAT's board of directors. The capital structure of the CAT underwent major changes in its early history as the Bank held only $20 \%$ of the total shares when the first annual shareholders meeting took place. However, the dominant position of the Bank was not questioned:

sented a considerable initial investment. Moreover, the lessee had to acquire existing inventories of raw materials and stored products, which, though subject to bargaining, amounted to approximately 50.9 million pesetas [AHBE, Sec. 789]. Putting all these figures together, the investment could be as high as 258 million pesetas, an amount that had to be added to the resources needed to run daily operations.

${ }^{2}$ Nevertheless, as Comin [1996, p. 149] stated, "the Bank of Spain was, until 1962, a private owned company, pursuing as such, profit maximisation in its financial operations, in order to distribute dividends, as required by shareholders. Whereas the Bank interacted closely with the state, it did so to obtain a return. Moreover, in those cases in which doubts on the profitability of cooperation existed, it simply refused to collaborate with the Government, as was, for instance, the case in 1850." This is to say that cooperation did not imply that the Bank was semi-public in nature. Rather, it was a fully privately-owned entity whose shares were listed on the Madrid Stock Exchange. 
Once the issue of the social capital was solved, the Commission thought that it should reserve for the Organisation the majority on the Board of the new Society, as the lease management fundamental guarantee, both to the Bank itself and to HM. government in their reciprocal relationships [AHBE, Operaciones, $\mathrm{n}^{\circ}$ 954].

Nine directors, the general manager, and the vice-president of the CAT were members of its board, five of whom sat on the Bank's board as well, thus assuring control over the firm's activities. Additionally, the Bank monitored the CAT's activities strictly and controlled its cash flows. The Bank was the exclusive financial intermediary with which the CAT was allowed to negotiate. It intervened in every transaction carried out by the CAT [Art. 37, Company's Statutes, REBE, e22301].

\section{THE IMPACT OF PRIVATIZATION ON MANAGEMENT ACCOUNTING SYSTEMS}

Management Accounting Systems under Public Administration: This section will focus on the tobacco factory of Seville, which was the largest and more complex of the factories constituting the monopoly. The activities of the factory at Seville were concentrated in three main product lines: cigars, cigarettes, and plug tobacco. Additionally, some sporadic dealings in rapé (French snuff) were undertaken. Though Spanish snuff production was legally stopped by 1840 , some accounting records were retained in order to control existing inventories.

Under public administration, accounting was divided into two main sections: 'accounting office' and 'factories'. The factories' accounts were the responsibility of operating managers, middle managers, and maestras, while the accounting office was under the charge of the accountant, assisted by several clerks and bookkeepers. The accounting office was in charge of monitoring and controlling the techniques developed in the factory. It examined, censored, and arranged all the factories' accounts to assure their conformity with the general accounts. The series of accounts of the 'accounting office' can be divided in two categories: general accounting and treasury (cash) (see Figure 1).

The factories' accounts were comprised of six basic sets of accounts: Cigars, Plug Tobacco, Cigarettes, Rapé, Snuff, and Intervention. These described in physical units the different productive processes and screened the progress of raw material through production stages [e.g., legs. 1640, 2176, and libros 1082, 1084, AHFTS]. Raw materials were received in General 


\section{FIGURE 1}

\section{Factories' Accounting Under Public Administration}

\begin{tabular}{|c|c|}
\hline \multicolumn{2}{|c|}{ ACCOUNTING OFFICE } \\
\hline GENERAL ACCOUNTS & TREASURY \\
\hline $\begin{array}{l}\text { 1. Alcaidia: reception and } \\
\text { outlet of tobacco }\end{array}$ & $\begin{array}{l}\text { 1. General Charge/ } \\
\text { discharge Accounts }\end{array}$ \\
\hline $\begin{array}{l}\text { 2. General Manufactur- } \\
\text { ing Accounts: }\end{array}$ & 2. Balance Books \\
\hline $\begin{array}{ll}\text { 2.1. } & \text { Packaging and } \\
\text { Bottling } \\
\text { 2.2. } & \text { Finished Products }\end{array}$ & $\begin{array}{l}\text { 3. Justifications and } \\
\text { Expenses Book }\end{array}$ \\
\hline 2.3. Tobacco Leaves & 4. Payment Justifications \\
\hline $\begin{array}{l}\text { 3. Statements to be sent } \\
\text { to Central Administra- } \\
\text { tion: }\end{array}$ & $\begin{array}{l}5 \text { Auxiliary book for cash } \\
\text { entries }\end{array}$ \\
\hline $\begin{array}{l}\text { 3.1. Public incomes } \\
\text { 3.2. Public expenses }\end{array}$ & 6. Salaries and wages \\
\hline $\begin{array}{l}\text { 3.3. Budgets and } \\
\text { consignments }\end{array}$ & $\begin{array}{l}\text { 7. List of workshop } \\
\text { employees }\end{array}$ \\
\hline 3.4. Cost accounts & 8. Retention (liabilities, \\
\hline $\begin{array}{l}\text { 4. Inventories and } \\
\text { General Re-weights }\end{array}$ & pension, etc.) \\
\hline
\end{tabular}

1.2. Cigars

FACTORIES

1. Cigars

1.1. General account:

1.1.1. Stores

1.1.2. General summary

1.1.3. Weekly notes

1.1.4. Annual account

1.3. Workshops

1.4. Finished Products

2. Plug Tobacco

2.1. Tobacco leaves in stores

2.2. Plug in Machines

2.3. Bottled Plug

2.4. Plug in distribution stage

3. Cigarettes

3.1. Workshops

3.2. Notebooks

4. Snuff

4.1. Snuff account

5. Rapé

5.1. Tobacco leaves

5.2. Rolls

5.3. Machines

5.4. Repose

5.5. Fermentation

6. Intervention
6.1. Materials entrance and outlet
6.2. General outlet
6.3. Bills

Store, where different accounts were held to register the reception and subsequent reallocation of tobacco leaves and auxiliary materials to the different factories and workshops. Operating managers had to render accounts for the raw material distributed to each workshop; the volume of discards, stems, or waste; and the final production manufactured daily. Changes reflected 
by these accounts were shaped by modifications in production processes or products.

The same accounts were registered in "Intervention" so that the accounting office could check the figures exhibited [e.g., libro 599, AHFTS]. When discrepancies were found, the accounting office started the process of determining who was responsible. Otherwise, the accounts were summed and checked in order to forward them to the pertinent offices in Madrid, where the figures were rechecked and compared with the resources allocated to each factory.

The General Accounts were comprised of five basic sets of accounts that had to be sent to several public institutions. Reception and Outlet of Tobacco and Other Materials [e.g., libros 1074, 1080 AHFTS] controlled for all factors of production entering and exiting the factory. General Manufacturing Accounts [e.g., leg. 2286, AHFTS] were compiled on the basis of information provided by the factories' accounts. There were three different accounts (Packaging and Bottling, Finished Products, and Tobacco Leaves), all of which tracked the inventories of all materials and production by class of product. These accounts were kept in physical units since their main purpose was to help the central services devise the operations schedule. The SATM established the monthly volume to be manufactured of every product in every factory, taking into account consumption trends in different geographical areas, the existing inventories in the factories, and their productive capacity. The Statements to be Sent to the Central Offices [e.g., leg. 2169, AHFTS] included four basic accounts (Public Revenues, Public Expenses, Budgets, and Consignments, and Cost Accounts). While the first of these was not relevant in the context of the factory, Public Expenses and Budgets reported the basic accounts for decision-making purposes. Financial resources were allocated using monthly budgets prepared by the factories, while expense accounts served to certify the use of such resources. Yearly cost calculations were also to be sent to the central offices. Inventories and General Reweights [e.g., leg. 2357, AHFTS] tracked the physical inventories that were carried out yearly. Finally, in Outlet Accounts [e.g., libro 902, AHFTS], all items that left the factory were recorded.

Finally, the Treasury (cash) section included a set of eight accounts that controlled the flow of cash, as well as the source materials documenting those flows. The General Charge/Discharge Cash Account was the most important as it provided the basic information required to compile the Statements to be Sent to the Central Offices. 
The charge/discharge bookkeeping method allowed a strict control of tobacco flow. As a reflection of the fiduciary nature of ownership, accounting systems under public administration were complex and subject to duplication. The main purpose of these systems was to ensure the proper use of public resources, but they provided little help in decision making. Operating managers, the accountant, and the factory's director were considered personally responsible for any shortage of tobacco. Accounting was the basic tool utilized to control their behavior.

To sum up, the main characteristics of the accounting systems under public direct management were:

1. Heterogeneity in the specific accounting systems implemented in the factories. This derived from the concern with monitoring the physical flows at the various stages of production. Accounting systems were highly dependent on the nature and organization of the production process.

2. Accounting systems focused on ensuring the legal use of resources, both physical and financial, leaving aside managerial aspects. This lack of managerial concern was enhanced by two factors: (i) the profitability of the industry guaranteed by the monopoly, and (ii) the fragmenting of the monopoly into three main branches (acquisition, manufacturing, and distribution), each managed by different administrative entities. To a large extent, there was no accounting consideration of the business as a whole.

Post-privatization Management Accounting Systems: Despite the general agreement that it is not ownership itself but managerial accountability that may fundamentally distinguish public from private enterprises [e.g., Vickers and Yarrow, 1988; Donahue, 1989; Jensen, 1989; Zeckhauser and Horn, 1989; Goodman and Loveman, 1991], most of the research on privatization has focused on the financial effectiveness of such processes rather than on the differences in methods utilized to control managerial behavior. Agency theory predicts that privatization will lead to the design of new managerial controls, including accounting systems. However, research has focused on capital markets as a means to monitor management. This is the general case in Anglo-Saxon settings where capital markets are well-developed. This assumption, however, is not so clear in contexts such as less-developed countries, like 19th century Spain, where external control mechanisms were weak and economic activity in 
general appeared to be strongly influenced by government. In these cases, the role of the state and the kind of capital the privatized firm attracted may help to explain the impact of privatization on the design of control mechanisms.

The privatization of the tobacco monopoly brought about, in accordance with the theoretical predictions, a change in management accounting systems. However, the change was not immediate. At first, the CAT decided to keep the basics of the former system so that managers could study information needs and the most efficient ways to satisfy them, while simply introducing some modifications to provide more useful information. However, the intention of the CAT to change the accounting system was made clear immediately after privatization. This was reflected in a letter of July 8, 1887:

... while this General Direction decides how should the Tobacco Factories' accounting be organised and the way in which charge and discharge books should be kept by the different units under your responsibility, you shall continue accounting operations according to the current system [AIFTS, leg. 354].

In January 1889, a new accounting system was implemented [AIFTS, leg.2]. The CAT designed an integrated system, common to all the factories. The system was articulated on four basic accounts: Tobacco Leaves, Packaging and Bottling, Manufacturing, and Cash. The Manufacturing and Cash accounts represented the basic instruments of overall management and control, while the Tobacco Leaves and Bottling and Packaging accounts were used mainly for internal control inside the individual factory. The Cash account was considered the most important for it served to articulate the general accounting for the enterprise.

These four accounts were prepared on the basis provided by a set of auxiliary accounts that described the different activities developed in the factories: Work in Progress [e.g., libro 600, AIFTS], Stored Products [e.g., libro 583, AIFTS], General Manufacturing Expenses [e.g., libro 585, AIFTS], and Losses and Benefits in Different Materials [e.g., libro 599, AIFTS] (see Figure 2). Finally, the system included four auxiliary books for Intervention and Cash [e.g., libros 592-597, AIFTS].

As shown in Figure 2, the pivot of the new system was the Work in Progress account. This book contained a separate sheet for every product, with debits for all manufacturing expenses and credits for finished products transferred to General Store. 


\section{FIGURE 2}

Factories' Accounting Under Private Management

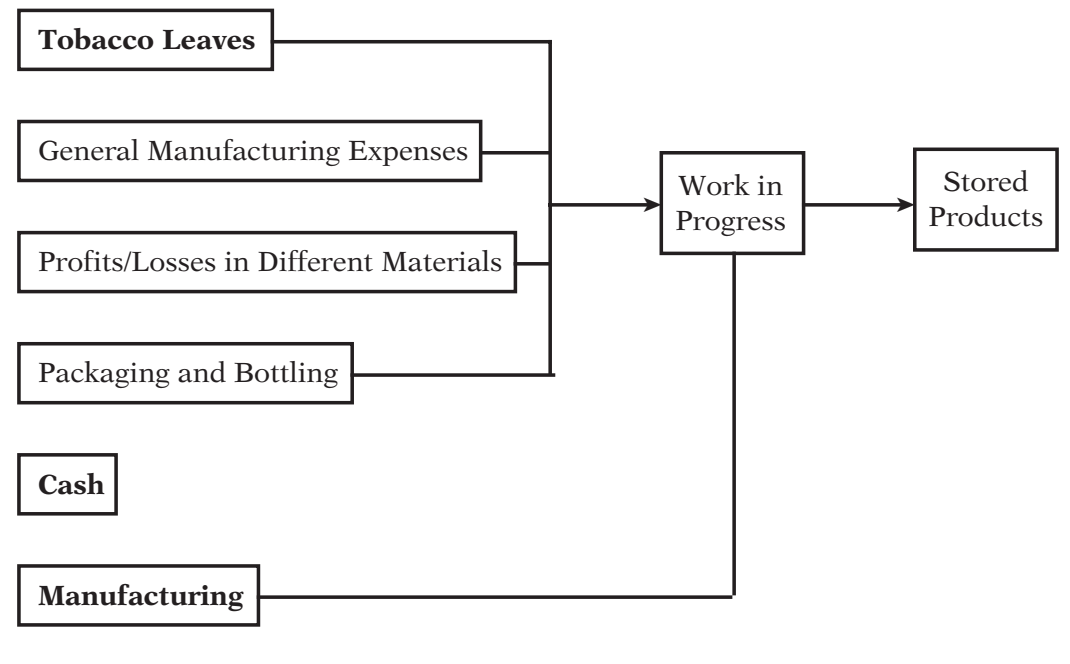

This account was related to the Packaging and Bottling, Tobacco Leaves, General Manufacturing Expenses, and Losses/profits from Different Materials accounts. The latter monitored the use of prime or auxiliary materials, being debited for scrap, waste, or stems of tobacco leaves, useless packaging, and other auxiliary materials and credited when these residuals, by-products, or stem were sold out. The Manufacturing account and the Work in Progress accounts showed a similar structure, both disclosing the cost at the factory level (that is, without including the apportionment of general administration and distribution costs) of the manufactured products.

The Tobacco Leaves, Packaging and Bottling, Work in Progress, Stored Products, and Cash accounts were to be balanced monthly with the results sent to Madrid within the period spanning the last day of the closing month and the first days of the next month. This duty was subject to financial sanctions (of 25 pesetas in 1889 [leg. 2, AIFTS]). Accounting information was complemented by other statements containing information on employees, budgets, and entry inspections of raw materials that were not classified as accounting data per se.

Cost accounting also experienced significant changes in two respects. First, costing records became fully integrated into the main accounting system. Costs were determined monthly in the Work in Progress account and were also reflected in the Manu- 
facturing account, corroborating the findings of Boyns and Edwards [1997] for the U.K. coal, iron, and steel industries. The integration of cost calculations in the general accounting system enhanced the regularity of reporting both because costs were reported monthly and because factories complied with these requirements. Under public administration, the tobacco factories had been required to prepare yearly cost calculations, but this information was not regularly reported.

Cost calculations underwent a major transformation since the common price per type of raw material was abandoned in order to calculate what was termed 'real' cost of products [Delgado, 1896]. Prior to privatization, the Treasury calculated a common weighted cost for raw materials. The reason for this, as stated by the Treasury, was to avoid differences in costs due to the variability of purchase prices. To resolve this problem, the accounting office provided factories with a yearly weighted-average cost of raw materials to be used by all factories. Cost information was required to control the efficiency within the different factories, so it made no sense to account for cost differences that were beyond the scope of managerial control. The CAT understood that with this system some 'low class' products were subsidizing 'high class' products, resulting in incorrect calculations of product margins. This could affect decision making with regard to product mix. Hence, immediately after privatization, the calculation method was changed to one based on using the real cost of the raw material consumed. Overheads continued to be allocated using the same system as under public control; i.e., they were allocated to products either according to the volume of raw material or the level of production. Cost reports included the matching of sales revenues against the cost associated with particular products, providing information about the profitability of individual product lines.

The Use of Cost Reports: Several uses of cost accounting may be outlined. First, cost accounting was used for inventory valuation. According to the 1885 Code of Commerce [Art. 157], private corporations should prepare and publish a monthly balance sheet in the Madrid Gazette. To comply with this requirement, inventories had to be valued. Second, evidence of the use of cost calculations for decision making appeared immediately after privatization, although still based on the public accounting system. For instance, cost information was used for production decisions. The new calculation method revealed, as was mentioned above, that some high class products were not profitable 
for the CAT, as was the case for two types of cigars, Conchas and Regalias. The 1887-1888 annual report explained this issue:

The existing products and their related costs called the attention of the Board of Directors who soon felt the need to rectify the former simulated cost calculations, in order to know the real return of every product. It is clear that those products requiring high quality tobacco leaves ... benefited from such system [use of weighted average prices for raw material], damaging all those products consuming low quality leaves. The production of Conchas and Regalias were first interrupted and, after getting the governmental permission definitively eliminated [Memoria 1887/88, CAT, p. 14, AIFTS].

Another example of the use of cost information for decision making is also to be found in 1887. The CAT needed to reorganize workshops. As long as the number of workers could not be dramatically reduced, efforts were devoted to reducing labor costs. For instance, in a letter addressed to a factory manager on October 3, 1887, the company's general director said:

I hereby order the elaboration and dispatch to this office as soon as possible of a detailed statement containing the special, long and short, tipped and sticked, white and tobacco paper, cigarettes existing in that Factory as at 30 September. The statement shall show firstly their value at cost, secondly their value at sales price, and thirdly gross margin of the previously mentioned products. These statements should be accompanied by another showing the amount paid by hundred thousands of those products as wage expenses, disclosing the information by the different tasks stated in the Regulation $\mathrm{n}^{\circ} 3$, 5 October 1883.

Afterwards you will show how much a worker in those tasks could earn during both a day and a month, without any kind of limitation in scheduled tasks. Lastly, you shall propose the modifications and reductions you consider to be convenient in piece-rate, so that they diminish to a fair rate that, providing the worker with appropriate earnings according to the delicacy of their work, does not result in such a significant disproportion [Carta $\mathrm{n}^{\circ}$ 197, legajo 354, AHFTS].

The CAT gathered proposals from all the factories and modified piece rates accordingly. The use of cost information for labor cost reduction is also in evidence, in 1891 when a modification of the Work in Progress account was enacted. A 
new format was introduced, disclosing information on the use of raw material, and other uses of cost reports were suggested. The purposes of this reform, as stated by the CAT, were the following:

.... (i) to determine the maximum of stem, dust, waste and disposals that should result as average in the manufacturing and use of cut tobacco. . . ; (ii) to establish adequate wages for all tobacco products in every Factory; (iii) ... thereby we will be able to determine which Managers have devoted their efforts to comply with the Company's wishes; which ones have done their best, but did not succeed because of problems they surely will solve in the future; and, finally, which ones are opposing passive resistance to what is established in the Regulations.... While the previous period was considered as a test-period . . . since this current month we will punish those who do not achieve the outcomes that logically can be expected [Legajo $\mathrm{n}^{\circ} 4$, AIFTS].

This document suggests the use of cost reports for labor cost reduction, the establishment of standards, and managerial performance evaluation. According to the evidence found, privatization had no major implications for labor control which continued as it had done under public administration. Cigar rollers' production was carefully tracked since it constituted the basis for the determination of their salaries. Supervisors (maestras) were in charge of 'receiving' the production, rejecting those products that did not conform to specifications, and recording the daily production of the workshops. As mentioned above, both technical standards and piece rates were fixed by a number of regulations. The CAT tended to concentrate its efforts in those areas that were perceived as critical for the success of the company. As far as the work of the factories was concerned, the major problem was not to control the time of workers, but ensure the quality of their production, which was the responsibility of supervisors and managers.

Cost accounting provided information to monitor managerial behavior. The CAT's main purpose was to avoid laxness in the inspection of materials and products. Several reasons may explain this lack of concern with disciplining labor. Cigar rollers were subject to piece-rate wage systems that reduced the pressure to control time, but rather provided economic incentives to comply with budgeted production. However, controlling for absenteeism could have been an important issue, taking into account the characteristics of tobacco production which required 
high skills and dexterity. Absenteeism was high, but it did not represent a major problem because the existence of slack resources ensured that production schedules were easily met. Additionally, a fundamental reason lay in the role the government played protecting the cigar rollers against the CAT. This was evident immediately after the privatizing of the monopoly [Comín and Martín-Aceña, 1999]. The first president of the CAT initially attempted to impose a more severe disciplinary regime by reducing the flexibility of timetables and controlling for absenteeism in the Madrid factory. Cigar rollers reacted, as usual, in a rather violent way, and the president decided to lock the factory. The government reacted immediately, ordering the factory to be reopened. As a result of this confrontation, the president resigned, and the CAT came to understand that avoiding conflicts with labor was more important than increasing discipline if good relations were to continue with the government.

\section{DISCUSSION}

Privatization processes represent an area of growing interest the economics and management literature. However, research has focused on developed economies characterized by strong, external control mechanisms. Evidence relating to contexts in which external control mechanisms are not well-developed remain scarce. Moreover, little is known about the impact of such processes on accounting systems. This paper by addressing the case of the 1887 Spanish tobacco monopoly privatization attempts to add evidence on the impact of the shift in ownership on management accounting systems.

The privatization of the tobacco monopoly brought about the use of cost accounting for inventory valuation, decisionmaking, and performance evaluation purposes. Privatization meant the emergence of a new philosophy with regard to the objectives of the firm. A focus on efficiency and profitability replaced the former emphasis on legality and fraud prevention. In this paper, it is argued that these new concerns, and the subsequent change in the management accounting system, were shaped by the contracts regulating the CAT's activities that, in fact, reflected the influence of the two main principals, the state and the Bank of Spain.

The influence of the Bank of Spain is evident in both the foundation of the CAT and its further development. The Company's Act ensured the Bank's domination of the board of directors and the shareholder's annual meeting in spite of its 
stake of only $20 \%$ of the shares. The Bank designed a highly centralized organization in which managers acted as a mere link between the board and the factories. Two reasons explain the Bank's incentive to exert direct control. On the one hand, the Bank was linked to the tobacco industry by the tacit commitment it held from the state. Any change in its status as the major shareholder could affect its relationship with the government and would damage the Bank's other business. On the other hand, the Bank itself was an agent and, as such, it tried to protect the interests of its shareholders. These were not always aligned with the CAT's shareholders' interests. ${ }^{3}$

Since granting the monopoly and retaining ownership of long-term assets, the state became the CAT's other major principal, as their relationship was regulated by the leasing contract. The government's attitude towards the tobacco monopoly experienced a major shift. This change is to be seen both with the sudden concern about profitability and efficiency and in the state's determination to discipline the CAT's management [Aharoni, 2000] over the role of accounting information. Several factors may explain the state's focus on profitability. First, and most obviously, the rental depended on net income. Second, information asymmetry was high since the governmental delegate had no seat on the board of directors. Although the state's representative was given broad powers in the management of the industry, it was accounting information that became the basic control mechanism. Third, the leasing contract forced the CAT to keep "proper and regular" accounting information with the delegate controlling compliance with this requirement. Finally, the financial pressure and the strategic constraints imposed by the leasing contract resulted in cost-saving strategies as the clearest way to improve performance [Uttley and Hooper, 1993].

To sum up, changes in the ownership structure not only brought about new incentives to control, but a fundamental shift in the object of control, with profitability and efficiency now privileged. These new economic concerns induced demands

${ }^{3}$ Evidence of the existence of conflicts of interest between the CAT and the Bank of Spain is ample. For instance, the Bank impeded any issue of shares since it obtained significant gains on its loans to the CAT [Comín and Martín Aceña, 1999]. Likewise, in the discussions preceding the reform of the Company Act in 1894, minority shareholders contested the dominance of the Bank in the management of the CAT and its position as the exclusive financial institution. However, this situation remained unchanged [AHBE, legajo 789]. 
for accounting information and a system redesign to generate the data required. While accounting systems both before and after privatization enabled coordination of flows between operating units, the new system was implemented both for decisionmaking and performance-evaluation purposes. Simplification, uniformity, and the integration of cost calculations in the main accounting systems were the major features of the new system, facilitating its implementation and enhancing compliance with accounting reporting norms.

Efficient decision making required the provision of timely, uniform, and regular information. These were basic prerequisites for the quality statistical information considered essential for decision making [Delgado, 1896]. Simplification of the system allowed a greater regularity and timeliness without increasing agency costs. Double-entry bookkeeping was critical in achieving this simplification and encouraged the required degree of control over activities. Uniformity of accounting records between factories permitted the board of directors to centralize decision making. Finally, the integration of cost calculations in the general accounting system of the CAT increased compliance with cost accounting duties, allowing performance appraisal and control over factory managers.

The evidence presented is consistent with recent literature on privatization which highlights the need to focus on the role of government and the capital structure in contexts where external control mechanisms are not well-developed [Dharwadkar, 2000; Ramamurti, 2000; Toninelli, 2000]. Future, comparative work on the design and development of management systems in regulated and emerging economies will certainly enhance our understanding of the underpinnings of such systems.

\section{CONCLUSIONS}

Accounting historians have drawn on two main theoretical perspectives to explain the motives for the emergence of cost accounting practices and understanding its implications. The economic rationalists and Foucauldian perspectives both locate the emergence of administrative coordination in the U.K. and U.S. during the late 18 th and early 19 th centuries. The major points of disagreement are to be found in (i) the concept of modern managerial control, (ii) the motives behind its emergence, and (iii) the implications of such practices.

Economic rationalists have argued that cost accounting emerged in response to new demands for managerial control. 
They suggest that factors such as size and complexity, competitive pressures, technology, and/or the need for coordination are the prime engines for accounting change. This perspective takes an implicit economic rationale that has been criticized for taking a functionalist view of organizations, neglecting other wider social, political, and cultural factors.

Foucauldian scholars have provided an alternative explanation for the emergence of modern managerial control. The translation of writing, examining and grading practices into the economic sphere [Hoskin and Macve, 2000] is considered to represent the major discontinuity in the history of accounting in the last three centuries. The application of these technologies to monitor worker performance allowed the implementation of a new disciplinary regime that enabled hierarchical surveillance [Hoskin and Macve, 1994]. An important aspect of this new disciplinary regime was the development of standards of work performance. This managerialism was exercised grammatocentrically and allowed the implementation of a positive system of power [Hoskin and Macve, 2000].

There have been various challenges to both perspectives [e.g., Hoskin and Macve, 2000; Boyns and Edwards, 1996, 2000]. However, for the purposes of this paper, one aspect is especially relevant. The main emphasis of the Foucauldian perspective has been to pinpoint the genesis of managerialism, identifying the moment and place when modern managerial control can be said to have emerged. This perspective offers limited assistance in explaining localized cases of accounting change, such as the one presented in this paper, where no changes in labor control were found. Economic perspectives, by contrast, offer a more general framework with which to address the study of accounting change at any level. This paper has tended toward the economic rationalist perspective.

It has been shown that the main characteristics of the industry remained stable. Factors such as size and complexity, technology, competitive pressure, and the need for coordination were not subject to major upheaval. In spite of this stability, the accounting system underwent significant change shaped by the shift in ownership. Privatization gave rise to new agency relationships; the contracts regulating them provided new incentives to control and, hence, new demands for accounting information. The evidence provided in this paper shows how cost accounting contributed to the monitoring of managerial performance. However, while the use of cost accounting for decision making (e.g., product mix or labor cost reduction) appeared immediately after 
privatization, it was in 1891 that its use for managerial control was explicitly stated as an objective. This is consistent with Chandler's [1977] analysis of the U.S. managerial revolution where, as Boyns and Edwards [1996: p. 41] have highlighted, "information originally conceived to enable efficient coordination was recognized as having potential to assess managerial performance." When comparing Anglo-Saxon and non-AngloSaxon contexts, although there may be similarities in the nature and direction of accounting change, significant differences may be found in the factors giving rise to such changes.

\section{REFERENCES}

Primary sources:

Archivo Histórico de la Fábrica de Tabacos de Sevilla:

Legajo 354: Correspondencia con los directores-administradores generales de la renta, Compañía Arrendataria y autoridades-particulares, 1887.

Legajo 1640: Libros del cargo y data general y libros de la data general (cigarros), 1830-1833.

Legajo 2169: Estados que se envían a la Dirección General de Rentas, 18761881.

Legajo 2176: Cuadernos del cargo y data (cigarros), 1835-1841.

Legajo 2286: Cuentas generales de fabricación, 1868-1887.

Legajo 2357: Balances y repesos generales, 1881-1887.

Libro 599: Libro de cuentas de entrada y salida de tabacos y efectos, 1854.

Libro 902: Libros de cuentas entrada y salida de tabacos y efectos, 18751876.

Libro 1074: Libros acopios salidas de tabacos a administraciones, 1852.

Libro 1080: Libro acopios tabacos salidos a administraciones, 1853.

Libro 1082: Libro del cargo y data de talleres, 1854.

Libro 1084: Libros del cargo y data de cigarros elaborados, 1854.

Archivo Intermedio Fábrica de Tabacos de Sevilla:

Legajo 2: Correspondencia Dirección y Particulares, 1889.

Legajo 4: Correspondencia con la Compañía Arrendataria, 1891.

Libro 583: Libro de labores almacenadas.

Libro 585: Libro de Gastos generales de fabricación.

Libro 592: Auxiliar de Intervención $n^{\circ} 2$.

Libro 593: Auxiliar de Intervención nº 3.

Libro 594: Auxiliar de Caja.

Libro 595: Intervención, Libro auxiliar de Intervención.

Libro 597: Libro auxiliar de Caja.

Libro 599: Libro de perjuicios y beneficios en distintas materias, $\mathrm{n}^{\circ} 1$.

Libro 600: Labores en Talleres.

Memoria 1887/1888, Compañía Arrendataria de Tabacos (CAT).

Archivo Histórico del Banco de España:

Legajo 954, serie Operaciones.

Archivo Especial de Registro, e-22.301.

Legajo 789, serie Secretaría. 
Secondary Sources:

Aharoni, Y. (2000), "The Performance of State-Owned Enterprises," in Toninelli, P.A. (ed.), The Rise and Fall of State-Owned Enterprise in the Western World (Cambridge: Cambridge University Press): 49-72.

Alonso Alvarez, L. (1996), "Estrategias Empresariales de los Monopolios Españoles: de la Gestión Pública a la Gestión Privada en el Estanco del Tabaco, 1887-1936," in Comín, F. and Martín Aceña, P. (eds.), La Empresa en la Historia de España (Madrid: Colección Economía, Civitas): 383-398.

Bös, D. (1991), Privatization. A Theoretical Treatment (Oxford: Clarendon Press).

Boyns, T. and Edwards, J.R. (1996), "The Development of Accounting in Midnineteenth Century Britain: A Non-disciplinary View," Accounting, Auditing and Accountability Journal, Vol. 9, No. 3: 40-60.

Boyns, T. and Edwards, J.R. (1997), "The Construction of Cost Accounting Systems in Britain to 1900: The Case of the Coal, Iron and Steel Industries," Business History, Vol. 39, No. 3: 1-29.

Boyns, T. and Edwards, J.R. (2000), "Pluralistic Approaches to Knowing More: A Comment on Hoskin and Macve," Accounting Historians Journal, Vol. 27, No. 1: 151-158.

Carmona, S., Ezzamel M., and Gutierrez, F. (1997), "Control and Cost Accounting Practices in the Spanish Royal Tobacco Factory," Accounting, Organizations and Society, Vol. 22, No. 5: 411- 446.

Carmona, S., Ezzamel, M., and Gutierrez, F. (1998), "Towards an Institutional Analysis of Accounting Change in the Royal Tobacco Factory of Seville," Accounting Historians Journal, Vol. 25, No. 1: 115-147.

Carmona, S. and Macías, M. (2001), "Institutional Pressures, Monopolistic Conditions, and the Implementation of Early Cost Management Practices. The Case of the Royal Tobacco Factory of Seville (1820-1887)," Abacus, Vol. 37, No. 2: 139-165.

Chandler, A.D., Jr. (1977), The Visible Hand: The Managerial Revolution in American Business (Cambridge, MA: Belknap Press).

Comín, F. (1996), Historia de la Hacienda Pública, II. España (1808-1995) (Barcelona: Crítica. Grijalbo Mondadori).

Comín, F. and Martín Aceña, P. (1999), Tabacalera y el Estanco del Tabaco en España (1636-1998) (Madrid: Fundación Tabacalera).

Dharwadkar, R. (2000), "Privatization in Emerging Economies: An Agency Theory Perspective," The Academy of Management Review, Vol. 25, No. 3: 650-670.

DeCastro, J. and Uhlenbruck, N. (1997), "Characteristics of Privatization: Evidence from Developed, Less Developed and Former Communist Countries," Journal of International Business Studies, Vol. 28, No. 1: 123-143.

Delgado, E. (1896), Anuario de la Renta de Tabacos (Madrid: Santías y de Figueroa).

Donahue, J.D. (1989), The Privatization Decision (New York: Basic Books).

Edwards, J.R. and Newell, E. (1991), "The Development of Industrial Cost and Management Accounting Before 1850: A Survey of the Evidence," Business History, Vol. 33, No. 1: 35-57.

Ezzamel, M.A., Hoskin, K.W., and Macve, R.H. (1990), "Managing it all by Numbers: A Review of Johnson \& Kaplan's Relevance Lost," Accounting and Business Research, Vol. 20, No. 78: 153-166.

Fama, E. and Jensen, M. (1983), "Separation of Ownership and Control," Journal of Law Economics, Vol. 26: 301-326.

Fleischman, R.K. and Parker, L.D. (1997), What is Past is Prologue: Cost Accounting in the British Industrial Revolution 1760-1850 (New York: Garland). 
Fleischman, R.K. and Parker, L.D. (1991), "British Entrepreneurs and Pre-Industrial Revolution Evidence of Cost Management," The Accounting Review, Vol. 66, No. 2: 361-375.

Freudenberg, T. and Bird, A. (1991), “An Outsider's Primer on East German Investment," Mergers and Acquisitions, Vol. 25, No. 5: 50-53.

García de Torres, J. (1884), Las Rentas Estancadas. Apuntes Históricos, Observaciones y Datos Estadísticos (Madrid: Imprenta de Loterías).

Goodman, J.B. and Loveman, G.W. (1991), "Does Privatization Serve the Public Interest?” Harvard Business Review, Vol. 69, No. 6: 26-38.

Hopper, T. and Armstrong, P. (1991), "Cost Accounting, Controlling Labour and the Rise of Conglomerates," Accounting, Organizations and Society, Vol. 16, No. 5/6: 405-438.

Hoskin, K.W. and Macve, R.H. (1986), "Accounting and the Examination: A Genealogy of Disciplinary Power," Accounting, Organizations and Society, Vol. 11, No. 2: 105-136.

Hoskin, K.W. and Macve, R.H. (1988), "The Genesis of Accountability: The West Point Connection," Accounting, Organizations and Society, Vol. 13, No. 1: 3773.

Hoskin, K.W. and Macve, R.H. (1994), "Reappraising the Genesis of Managerialism: A Re-examination of the Role of Accounting at the Springfield Armory, 1815-1845," Accounting, Auditing and Accountability Journal, Vol. 7, No. 2: 4-29.

Hoskin, K.W. and Macve, R.H. (2000), "Knowing More as Knowing Less? Alternative Histories of Cost and Management Accounting in the U.S. and the U.K.," Accounting Historians Journal, Vol. 27, No. 1: 91-149.

Instituto de Estudios Fiscales (1976): Datos Básicos para la Historia Financiera de España, 1850-1975, Vol. 1 (Madrid: Ministerio de Hacienda).

Jensen, M.C. (1989), "Eclipse of the Public Corporation," Harvard Business Review, Vol. 67, No. 5: 61-74.

Jensen, M. and Meckling, P. (1976), "Theory of the Firm: Managerial Behavior, Agency Costs, and Ownership Structure," Journal of Finance and Economics, Vol. 3: 305-360.

Johnson, H. and Kaplan, R. (1987), Relevance Lost: The Rise and Fall of Management Accounting (Boston: Harvard Business School Press).

Kornai, J. (1986), Contradictions and Dilemmas Studies on the Socialist Economy and Society (Cambridge: MIT Press).

Lane, J.E. (1997), "Incorporation as Public Sector Reform," in Lane, J.E. (ed.), Public Sector Reform. Rationales, Trends and Problems (London: Sage): 283300

Lenway, S.A. and Murtha, T.P. (1994), "The State as a Strategist in International Business Research," Journal of International Business Studies, Vol. 25, No. 3: 513-536.

Macías, M. (2002), "Ownership Structure and Accountability. The Case of the Spanish Tobacco Company (1887-1896)," Accounting, Business and Financial History, forthcoming.

Maureta, J.M. (1975), El Tabaco en el Monopolio Español y la Economía Mundial (Ph.D. dissertation, Universidad Complutense de Madrid).

Odgen, S. and Watson, R. (1996), "The Relationships between Changes in Incentives Structures, Executive Pay and Corporate Performance: Some Evidence from the Privatised Water Industry in England and Wales," Journal of Business and Accounting, Vol. 23, No. 5/6: 721-751.

Ramamurti, R. (2000), "A Multilevel Model of Privatization in Emerging Economies," The Academy of Management Review, Vol. 25, No. 3: 525-551. 
Rees, R. (1984), “A Positive Theory of the Public Enterprise," in Marchand, M., Pestieau, P., and Tulkens, H. (eds.), The Performance of Public Enterprises (Amsterdam: North-Holland): 179-191.

Rodríguez Gordillo, J.M. (1990), "El Tabaco: del Uso Medicinal a la Industrialización," Catálogo de la Exposición de la Agricultura Viajera (Madrid: Ministerio Agricultura): 53-81.

Stiglitz, J. (1989), The Economic Role of the State (Oxford: Basil Blackwell).

Tejerizo López, J.M. (1975), Los Monopolios Fiscales (Madrid: Instituto de Estudios Fiscales).

Toninelli, P.A. (2000), The Rise and Fall of State-Owned Enterprise in the Western World (Cambridge: Cambridge University Press).

Torres Villanueva, E. (1998), "La Fundación de la Compañía Arrendataria de Tabacos," Documento de Trabajo nf 9808, (Madrid: Fundación Empresa Pública).

Tyson, T.N., (1993), "Keeping the Record Straight: Foucauldian Revisionism and Nineteenth Century US Accounting History," Accounting, Auditing and Accountability Journal, Vol. 6, No. 2: 4-16.

Uhlenbruck, N. and DeCastro, J. (1998), "Privatization from the Acquirer's Perspective: A Mergers and Acquisitions Based Framework," Journal of Management Studies, Vol. 35, No. 5: 619-640.

Uttley, M. and Hooper, N. (1993), "The Political Economy of Competitive Tendering," in Clarke, T. and Pitelis, C. (eds.), The Political Economy of Privatization (London: Routledge): 145-158.

Utton, M.A. (1986), The Economics of Regulating Industry (Oxford: Basil Blackwell).

Vickers, J. and Yarrow, G. (1988), Privatisation: An Economic Analysis (Cambridge: MIT Press).

Wright, M. and Thompson, S. (1994), "Divestiture of Public Sector Assets," in Jackson, P.M. and Price, C.M. (eds.), Privatisation and Regulation: A Review of the Issues (London: Longman): 35-76.

Zeckhauser, R.J. and Horn, M. (1989), "The Control and Performance of State Owned Enterprises," in MacAvoy, P.W., Stanbury, W.T., Yarrow, G., and Zeckhauser, R.W. (eds.), Privatization and State Owned Enterprises: Lessons from the United States, Great Britain and Canada (Boston, MA: Kluwer): 757. 